\title{
THE EFFECT OF THE COVID-19 PANDEMIC ON THE CROATIAN ECONOMY
}

\author{
Vlasta Roška \\ PhD, Assistant Professor, Libertas International University, Faculty for International Business and \\ Economics, Trg J. F. Kennedy 6b, 10000 Zagreb, Croatia; e-mail:vroska@libertas.hr
}

\section{Anđelka Buneta}

$\mathrm{PhD}$, Senior Lecturer, Libertas International University, Faculty for International Business and Economics, Trg J. F. Kennedy 6b, 10000 Zagreb; e-mail: andelka.buneta1@gmail.com

\section{Milan Papić}

M.Sc., Senior Lecturer, Libertas International University, Faculty for International Business and Economics,

Trg J. F. Kennedy 6b, 10000 Zagreb, Croatia; e-mail: mpapic@libertas.hr

\begin{abstract}
This article titled "The effect of the COVID-19 pandemic on the Croatian economy" deals with exceedingly current events triggered by the pandemic, which have reflected on the national and global economy. Based on the currently available data and the survey of 358 respondents (from both the private entrepreneurship sector and public administration), the effect of COVID-19 on the Croatian economy is observed through declining employment, the required recovery years, and declining GDP. The differences and similarities between this and the great global economic crisis of 2008/2009 as well as the opinion of entrepreneurs on which crisis has had more significant consequences for the economy were examined. A linear regression model predicts the declining employment in the recovery years. The entrepreneurs agree that the crisis caused by the COVID-19 pandemic is far more destructive and devastating to the economy, primarily because there is no end in sight even though the vaccine has been found. The unanimous agreement of the entrepreneurs is that, without further measures aimed at preserving the economy put in place by the Government, it will not be possible to suppress a further decline in employment and GDP, which will lead to a prolongation of the necessary recovery time for the Croatian economy. This research is the basis for further research on the effect of the COVID-19 pandemic on the Croatian economy.
\end{abstract}

Key words: COVID-19 crisis, employment, Financial Crises, GDP 


\section{INTRODUCTION}

The global health crisis caused by COVID-19 is a unique example in the economic history, to date, of a rapid and profound impact on the world economy. Therefore, the states have had to undertake a number of measures to mitigate the health and economic consequences of the pandemic. The governments of many countries worldwide have reacted to the sudden halt in economic activity by increasing health care expenditures, transferring the funds to the entrepreneurs to preserve liquidity and save jobs, and by postponing tax and credit obligations. State interventions are particularly substantial in supporting business sectors, amounting to more than 10 percent of the GDP in most of the developed countries.

The fact that the world has experienced the COVID-19 crisis while facing an over-indebtedness after a multi-year trend of increasing indebtedness and insufficient recovery from the 2007 global financial crisis should not be overlooked. This is supported by the data on the historically largest share of the public debt (globally) in the GDP of 83 percent. According to the IMF estimates (Jurlin, 2020) for 2020, the share of the government GDP debt in the world will increase by 13.1 percent, and in the event of a new wave of the pandemic in 2021, they predict an additional increase of as much as 20 percent. According to Baker et al. (2020) the crisis caused by COVID-19 has led to an increase of uncertainty because there are no close parallels from the economic history with which a comparison could be made.

The chief economist of the World Bank, Justin Lin, estimated in early 2009 that the financial crisis would result in the most severe recession since the 1930s (Letica, 2010: 3). However, the COVID-19 pandemic, that emerged in the late 2019 in China and spilled over to the entire world in 2020, refuted all of the economists and analysts who thought the 2007 crisis was something that would have the most serious consequences for the economy. According to the El-Erian (Jeffery, 2020) the disorder caused by COVID-19 is not only destructive but has also created "shocks" of supply and demand in all areas of human activity. Some countries have imposed a total travel inside and outside of the country. Precisely because of this, the crisis caused by COVID-19 is a precedent in the history of economic crises.

The situation in the Republic of Croatia is even more alarming because the economy has not yet recovered from the great crisis of 2008 and has faced this situation very unprepared. Due to the partial or complete closure of factories and enterprises in March 2020, there was a decline in industrial production in almost all areas. According to the Central Bureau of Statistics (2020a), the quarterly GDP in the second quarter of 2020 was 15.1 percent lower than in the same quarter of 2019. This is the largest real decline in the quarterly GDP since 1995, when a quarterly estimate of GDP was instituted. Due to closures of world economies and the drop in demand, imports of goods have experienced a significant reduction, especially from the most important foreign trade partners from the European Union. The Republic of Croatia is among the three most severely affected countries. The European Commission (Eurostat, 2020) predicts the biggest drop in GDP to be in Italy, 11.2 percent, Spain 10.9 percent and Croatia 10.8 percent. Although, at first glance, the impact on the EU economy seems symmetrical as the pandemic has hit all Member States, a significant asymmetry of the economic downturn in 2020 and the recovery strength in 2021 is 
expected. According to the current forecasts of the European Commission, the differences in the extent of the consequences of the pandemic and the recovery strength among the Member States will be even more pronounced than expected in the spring forecast.

On average, the euro area economy will shrink by 8.7 percent in 2020 and grow by 6.1 percent in 2021. As for the EU-wide economy, it is projected to decline by 8.3 percent in 2020 and grow by about 5.8 percent in 2021. According to the current forecasts (ECB, 2020a), the decline in 2020 will be significantly higher than the 7.7 percent previously projected for the euro area and 7.4 percent projected for the $\mathrm{EU}$ as a whole in the spring forecast, as of May 6, 2020. In the wake of the presented forecasts for the Croatian and European economy, this research sought to examine whether the expectations of the entrepreneurs are consistent with the relevant projections of the Government, macroeconomists and the institutions in charge of calculating and monitoring GDP and other economic parameters in Croatia. The survey was conducted in the sixth month of this year on 358 respondents from various economic activities.

The following hypotheses have been set for testing the selected goal:

H1: According to the opinion of Croatian entrepreneurs COVID-19 crisis has and will have more significant consequences than the financial crisis of 2007/2008 (in Croatia 2008/2009)

H2: Entrepreneurs' opinions on the consequences of the crisis caused by the COVID-19 pandemic differ from the Government's assumptions

H3: Entrepreneurs' opinions on the consequences of the crisis caused by the COVID-19 pandemic differ from the assumptions of economic analysts

H4: There is no statistically significant difference between the opinions of entrepreneurs at various stages of post-lockdown mitigation on the economic consequences of the crisis caused by the COVID-19 pandemic in terms of GDP decline, declining of employment and the required recovery years.

The paper consists of six parts including the introduction and the conclusion. The remainder of the paper is organized as follows. Section 2 recalls the literature of theoretical and empirical studies that have examined various economic factors of COVID-19. Section 3 describes the data and the methodology. Section 4 reports the empirical data of the obtained by the research, and Section 5 reports the results of the empirical data and discusses the obtained results on the economic consequences of the COVID-19 crisis.

\section{LITERATURE REVIEW}

Considering that the research opus of the relevant empirical research papers related to the impact of COVID-19 on GDP is extremely modest, which is understandable given the very short time period and the large number of unknowns, the intention in this chapter is to combine the most important foreign and domestic research papers which are related, in both a broader and a narrower sense, to the topic of the impact of COVID-19 on GDP. 
The author Čvarak (2020), in his work, explores the macroeconomics of the crisis and how to approach its resolution. The article explains the health shock impact mechanisms on the economy and the macroeconomic framework of mitigation and the exit from the crisis. In the analysis, he uses the AS-AD model with inflation on the vertical axis for the Croatian data.

Cutic (2020) analysed the impact of the pandemic on the stability of the PESCO programme and the financing of the security and defence sector in the face of an almost complete cessation of economic activities. He concludes that the Government of the Republic of Croatia made timely decisions regarding the adjustment of the state budget to the new situation and has helped the businessmen.

In her work Maliszevska et.al. (2020) elaborate on an illustrative scenario in which they indicate that the potential loss of income and GDP in the affected countries could be significant. They announce that they will develop the analysis over time as more indicators emerge. Early indicators of economic costs and the magnitude of the estimated impacts indicate the need for a coordinated international crisis response.

Canuto (2020) analyses how quickly and to what extent the national economies will recover after a pandemic. It analyses the available world associations data such as the IMF, the World Bank and concludes that the global economy is expected to be marked after the pandemic by an even greater public debt, an acceleration of the digitalization process and a lesser globalization.

Brodeur et al. (2020) use the Real Business Cycle (RBC) model and conclude that the COVID-19 shock led to a year-on-year decline in GDP of 11 percent in the 4th quarter of 2020. According to the authors, more than half of the reduction was caused by the uncertainty caused by COVID-19.

Baker et al. (2020) conclude that COVID-19 has led to a large increase in uncertainty and state that there are no close historical parallels and that a major limitation in research is the very rapid data change.

In their study, Bonadio et al. (2020) use a quantitative framework to simulate a global blockade in terms of labour supply reductions for 64 countries. The authors find that the average decline in real GDP represents the main decline in the economic activity, which is largely attributed to the disruptions in global supply chains.

Caspedes et al. (2020) formulate a minimalist economic model in which COVID-19 leads to a loss of productivity. The authors predict a vicious circle triggered by a drop in productivity causing lower collateral values, which limits the amount of borrowing activity, leading to a reduction in employment and then back to lower productivity. The COVID-19 shock was also intensified through the loop of the 'unemployment' collapse and the deflation of property prices.

In a study by Coibion et al. (2020), surveys are to assess the macroeconomic expectations of U.S. households (by examining the expenditure decline).

Eleney et al. (2020) model the impact of COVID-19 as a decline in worker productivity and in labour supply, which, ultimately, adversely affects the revenues of various enterprises. Falling 
revenues and consequent non-payment of liabilities create a wave of corporate tasks that could bring down financial intermediaries.

\section{METHODOLOGY}

The aim of this study is to examine whether entrepreneurs' expectations about the economic consequences of the COVID-19 crisis coincide with the relevant projections of the macroeconomists and the institutions as well as of the Government of the Republic of Croatia in terms of GDP, unemployment and recovery years.

In order to test the set hypotheses after the usual descriptive statistics, a linear regression model and the Pearson Chi-Square Test are used. Pearson's chi-squared test is used to determine whether there is a statistically significant difference between the expected frequencies and the observed frequencies in one or more categories. The statistical study used the software IBM SPSS.

In the conducted research, a survey was used as an instrument for obtaining the opinion of various entrepreneurs. The research was conducted online in the period from 26.05. to 16.6.2020 in the conditions in which the business began to return to the new "normal". The survey questionnaire was conducted online to include a sample of respondents in different positions and in different economic activities, determine their attitude and forecasts with regard to the developing situation and compare their forecasts with the forecasts of the Government and the economic analysts and institutions.

In the survey questionnaire has answered 358 people. In the survey participated 77.9 percent of women and 22.1 percent of men. Among respondents, 51.4 percent were Manager / Owner, 7.3 percent were Managers, 15.6 percent Chiefs, 23.2 percent Employees in private companies and 2.5 percent were employees in a public administration. The survey questionnaire consists of two parts and a total of 44 questions. The first part contains 6 questions covering general information about the gender of the respondents, their job, the size of the company, the main activity of the company, the affiliation of the company to a particular county and the stages of relaxation after the lockdown. The second part refers to the state measures put in place to save the economy and the opinion of respondents on the future consequences of this COVID-19 pandemic caused crisis. The research presented in this paper refers to four questions in the second part, namely the insight of entrepreneurs on which crisis will have more significant consequences for the economy: COVID-19 crisis or the financial crisis 2007/2008 (or in the Republic of Croatia 2008/2009); and on the economic consequences of the COVID-19 crisis in terms of the falling GDP, falling employment, as well as the years of economic recovery needed to achieve business results as they were in 2019. Respondents' opinions on these elements were observed in terms of concessions after the lockdown that began on the 16th of March 2020, when all educational institutions and non-food stores were closed, and all services where the advised physical distance could not be maintained were suspended.

The easing of measures after the lockdown was accomplished in three phases. The first phase of easing the lockdown measures began on the $27^{\text {th }}$ of April 2020 with the opening of shops, public transport, and outdoor training. The second phase began on the $4^{\text {th }}$ of May 2020. It enabled the 
full operation of the health system, activities that provide personal services such as hairdressers, beauticians, barbers. The third phase began on the $11^{\text {th }}$ of May 2020 in which the gathering of up to 10 people was allowed as well as the work of shopping centres, kindergartens, classroom teaching, catering facilities and hotels, all under certain hygienic conditions. For the purposes of this research, five groups were created: the first three are made up of the official phases of concessions, the fourth consists of entrepreneurs from various industries who could not be placed in the above groups, while the fifth group consists of entrepreneurs who did not have any restrictions (the ones who did not have to suspend operations during lockdown). In the first phase (27.04.2020) was 8.9 percent of the respondents. In the second phase (4.05.2020) was placed 5.0 percent of the respondents. In the third phase (11.05.2020) was placed 12.9 percent of the respondents. The biggest part, 59.2 percent of the respondents did not have restrictions on activities. The 14.0 percent of the respondents were not sure about restrictions, because they are involved in a lot of different activities. First day of lockdown was 16.3.2020. The first phase was in lockdown for 42 days, the second phase for 49 days, and the third phase for 56 days. The other groups of respondents (groups 4 and 5) were not in the lockdown.

Table 1 shows the surveyed entrepreneurs according to the size of the company, classified according to the phases of measure relaxation. Most respondents belong to micro-entrepreneurs (65.6 percent), of which 41.6 percent did not stop working; 9.5 percent of micro-entrepreneurs could not be placed in any of the phases as they have more activities or some measures for their activities were not disclosed. In the first phase of the concession were 6.7 percent of micro-entrepreneurs and 5.6 percent in the third phase of the concession.

Table 1. The size of the companies according to the phase of COVID-19 measures relief

\begin{tabular}{|c|c|c|c|c|c|c|}
\hline \multirow[b]{2}{*}{ SIZE OF COMPANIES } & \multicolumn{5}{|c|}{ PHASE COVID-19 } & \multirow[b]{2}{*}{ Total } \\
\hline & $\begin{array}{c}\text { 1.P. } \\
(27.4 .)\end{array}$ & $\begin{array}{l}\text { 2. P. } \\
(4.5 .)\end{array}$ & $\begin{array}{c}\text { 3.P. } \\
(11.4 .)\end{array}$ & $\begin{array}{l}\text { NOTHING } \\
\text { MENTION }\end{array}$ & $\begin{array}{c}\text { DID NOT STOP } \\
\text { THE WORK }\end{array}$ & \\
\hline MICRO & $6.7 \%$ & $2.2 \%$ & $5.6 \%$ & $9.5 \%$ & $41.6 \%$ & $65.6 \%$ \\
\hline SMALL & $.6 \%$ & $.6 \%$ & $3.1 \%$ & $1.4 \%$ & $6.1 \%$ & $11.7 \%$ \\
\hline MEDIUM & $.8 \%$ & $.3 \%$ & $1.4 \%$ & $.3 \%$ & $3.1 \%$ & $5.9 \%$ \\
\hline LARGE & $.8 \%$ & $.8 \%$ & $2.5 \%$ & $1.7 \%$ & $2.2 \%$ & $8.1 \%$ \\
\hline $\begin{array}{l}\text { CRAFTMEN, I. } \\
\text { PROFESSION }\end{array}$ & $.0 \%$ & $1.1 \%$ & $.3 \%$ & $1.1 \%$ & $6.1 \%$ & $8.7 \%$ \\
\hline TOTAL & $8.9 \%$ & $5.0 \%$ & $12.8 \%$ & $14.0 \%$ & $59.2 \%$ & $100.0 \%$ \\
\hline
\end{tabular}

Table 2 shows the entrepreneurs who participated in the survey sorted by activities through certain phases of easing measures. Most entrepreneurs (59.2 percent) from the fifth phase, which had no restrictions in doing business, relate to accounting, auditing and tax consulting (36.6 percent). 
Table 2. Activities in the phases of COVID-19 measures relief

\begin{tabular}{|l|c|c|c|c|c|c|}
\hline \multirow{2}{*}{ ACTIVITIES } & \multicolumn{5}{|c|}{ PHASE COVID-19 } & \multirow{2}{*}{ Total } \\
\cline { 2 - 6 } & $\begin{array}{c}1 . \mathrm{P} . \\
(27.4 .)\end{array}$ & $\begin{array}{c}2 . \mathrm{P} . \\
(4.5 .)\end{array}$ & $\begin{array}{c}3 . \mathrm{P} . \\
(11.4 .)\end{array}$ & $\begin{array}{c}\text { NOTHING } \\
\text { MENTION }\end{array}$ & $\begin{array}{c}\text { DID NOT } \\
\text { STOP THE } \\
\text { WORK }\end{array}$ & \\
\hline CONSTRUCTION & $.6 \%$ & $.0 \%$ & $.0 \%$ & $.8 \%$ & $2.2 \%$ & $3.6 \%$ \\
\hline PUBLIC ADMIN. & $.6 \%$ & $.0 \%$ & $.3 \%$ & $.3 \%$ & $1.4 \%$ & $2.5 \%$ \\
\hline EDUCATION & $.3 \%$ & $.3 \%$ & $.8 \%$ & $.3 \%$ & $.3 \%$ & $2.0 \%$ \\
\hline AGRICULTURE & $.6 \%$ & $.0 \%$ & $.3 \%$ & $.0 \%$ & $.8 \%$ & $1.7 \%$ \\
\hline MANUFACT. IND. & $.6 \%$ & $.3 \%$ & $.6 \%$ & $.3 \%$ & $2.0 \%$ & $3.6 \%$ \\
\hline FOOD INDUS. & $.3 \%$ & $.0 \%$ & $.6 \%$ & $.6 \%$ & $.6 \%$ & $2.0 \%$ \\
\hline HOSPITALITYI. & $.6 \%$ & $.0 \%$ & $3.9 \%$ & $1.1 \%$ & $.8 \%$ & $6.4 \%$ \\
\hline FOOD TRADE & $.8 \%$ & $.0 \%$ & $.6 \%$ & $.8 \%$ & $2.5 \%$ & $4.7 \%$ \\
\hline TEHNICAL TR. & $2.0 \%$ & $.0 \%$ & $.6 \%$ & $.6 \%$ & $1.4 \%$ & $4.5 \%$ \\
\hline FINAN. AND INS. & $.3 \%$ & $.0 \%$ & $.8 \%$ & $.8 \%$ & $2.2 \%$ & $4.2 \%$ \\
\hline PERSONALS. & $.6 \%$ & $1.1 \%$ & $.6 \%$ & $.3 \%$ & $.8 \%$ & $3.4 \%$ \\
\hline ACC., AUD. TAX & $1.4 \%$ & $1.4 \%$ & $1.4 \%$ & $5.3 \%$ & $36.6 \%$ & $46.1 \%$ \\
\hline REST ACT. & $.6 \%$ & $2.0 \%$ & $2.5 \%$ & $2.8 \%$ & $7.5 \%$ & $15.4 \%$ \\
\hline TOTAL & $8.9 \%$ & $5.0 \%$ & $12.8 \%$ & $14.0 \%$ & $59.2 \%$ & $100.0 \%$ \\
\hline
\end{tabular}

Most of the respondents were from the City of Zagreb (30.2 percent); 17.0 percent did not stop the work; 4.7 percent was in the third phase. From the Split-Dalmatia County, (10.1 percent) 5.9 percent did not stop the work and 1.4 percent was in the first phase. From 21 Counties, only LikaSenj County is not present in this research.

In order to further compare the effects of the $2008 / 09$ crisis with the crisis caused by the COVID-19 pandemic, we determined a regression linear model (one could also say a trend-model because time is an independent variable) for the movement of the number of employed and unemployed.

A linear regression model was determined for the number of employed and unemployed based on empirical data for the period from 2008 to 2014. The obtained model equations were translated so that their starting point was in the 1 st quarter of 2020. Based on the thus translated model, a projection for 2020, 2021 and 2022 by quarters was made.

\section{EMPIRICAL DATA AND THE ANALYSIS}

As the main goal of this paper is to determine the opinion of the respondents - entrepreneurs of different size, activities and from different counties, they were asked basic questions divided into 
four variables: 1) which crisis had the more significant consequences for the Croatian economy: the crisis of 2008/2009 or COVID -19 crisis according to the opinions of the entrepreneurs; 2) how many years will it take for the economy to recover in order to achieve the results of 2019;3) how big a decline in employment due to the COVID-19 crisis is expected by the end of 2020; 4) how big a decline in GDP is expected as a result of the COVID-19 crisis in 2020. The obtained results from the entrepreneurs, based on the survey questionnaire, are shown in Table 3 and were used to achieve the main goal of this paper and by either confirming or rejecting the aforementioned hypotheses.

When asked which crisis had the more significant consequences for the economy, 69.6 percent of the respondents answered that it was the COVID-19 crisis, which is statistically significantly more $(\chi 2=54.75, p<0.01)$ than the respondents who believe that the crisis of 2008/09 had greater consequences (30.4 percent). There is no statistically significant difference $(\chi 2(4)=3.423$, $\mathrm{p}=.490$ ) between the respondents in different phases of the COVID-19 relief measures giving greater significance to the COVID-19 crisis; although, 39.7 percent of the respondents who gave greater significance to the COVID-19 crisis did not have business downtime.

When asked how long the recovery will be to once again reach the results of 2019, 48.6 percent predict a period of at least 3 years, and 21.2 percent up to 5 years. However, there is no statistically significant differences $(\chi 2(16)=22.605, p=.125)$ between the respondents in different phases of COVID-19 mitigation measures and predicted years of recovery for the economy.

When asked what decline in employment is expected by the end of the year, 63.1 percent answered between 11 and 30 percent. There is no statistically significant difference $(\chi 2(12)=18.918$, $\mathrm{p}=.091$ ) between the respondents in different phases of the COVID-19 relief measures in reference to the question of the employment decline. 38.3 percent from the group of entrepreneurs who did not have a business interruption and 5.3 percent of entrepreneurs from the first phase.

When asked how big a decline in GDP is expected as a result of the COVID-19 crisis in the Republic of Croatia, as many as 67.9 percent of entrepreneurs agreed with the predictions of the economic analysts. There is no statistically significant difference $(\chi 2(16)=17.786, p=.337)$ between the respondents in different phases of the COVID-19 relief measures and the predicted drop in GDP. 39.9 percent of entrepreneurs who did not have a business interruption. 
Table 3. Pearson Chi-Square Test

\begin{tabular}{|c|c|c|c|c|c|c|c|c|c|}
\hline \multirow[b]{2}{*}{ Description } & \multicolumn{5}{|c|}{ PHASE OF COVID-19 } & \multirow[b]{2}{*}{ Total } & \multirow[b]{2}{*}{$\begin{array}{c}\text { Pearson } \\
\text { Chi- } \\
\text { Square }\end{array}$} & \multirow[b]{2}{*}{ df } & \multirow[b]{2}{*}{$\begin{array}{l}\text { Asymp. } \\
\text { Sig. (2- } \\
\text { sid.) }\end{array}$} \\
\hline & $\begin{array}{c}\text { 1. P. } \\
(27.4 .)\end{array}$ & $\begin{array}{l}\text { 2. P. } \\
(4.5 .)\end{array}$ & $\begin{array}{c}\text { 3. P. } \\
(11.5 .)\end{array}$ & $\begin{array}{l}\text { NOTHING } \\
\text { MENTION }\end{array}$ & $\begin{array}{c}\text { DID } \\
\text { NOT } \\
\text { HAVE } \\
\text { STOP } \\
\text { THE } \\
\text { WORK }\end{array}$ & & & & \\
\hline CRISES & $8.9 \%$ & $5.0 \%$ & $12.8 \%$ & $14.0 \%$ & $59.2 \%$ & $100.0 \%$ & 3.423 & 4 & .490 \\
\hline CRISIS 2008/2009 & $2.8 \%$ & $1.7 \%$ & $3.6 \%$ & $2.8 \%$ & $19.6 \%$ & $30.4 \%$ & & & \\
\hline COVID-19 CRISIS & $6.1 \%$ & $3.4 \%$ & $9.2 \%$ & $11.2 \%$ & $39.7 \%$ & $69.6 \%$ & & & \\
\hline RECOVERY YEAR & $8.9 \%$ & $5.0 \%$ & $12.8 \%$ & $14.0 \%$ & $59.2 \%$ & $100.0 \%$ & 22.605 & 16 & .125 \\
\hline $1 \mathrm{Y}$ & $1.4 \%$ & $1.7 \%$ & $1.4 \%$ & $1.7 \%$ & $13.7 \%$ & $19.8 \%$ & & & \\
\hline $3 Y$ & $3.9 \%$ & $2.2 \%$ & $8.7 \%$ & $6.1 \%$ & $27.7 \%$ & $48.6 \%$ & & & \\
\hline $5 Y$ & $2.2 \%$ & $1.1 \%$ & $2.2 \%$ & $3.4 \%$ & $12.3 \%$ & $21.2 \%$ & & & \\
\hline $10 Y$ & $1.4 \%$ & $.0 \%$ & $.6 \%$ & $2.2 \%$ & $4.2 \%$ & $8.4 \%$ & & & \\
\hline$>10 \mathrm{Y}$ & $.0 \%$ & $.0 \%$ & $.0 \%$ & $.6 \%$ & $1.4 \%$ & $2.0 \%$ & & & \\
\hline $\begin{array}{l}\text { DECLINE IN } \\
\text { EMPLOYM. }\end{array}$ & $8.9 \%$ & $5.0 \%$ & $12.8 \%$ & $14.0 \%$ & $59.2 \%$ & $100.0 \%$ & 18.918 & 12 & .091 \\
\hline TO $10 \%$ & $1.4 \%$ & $.8 \%$ & $2.2 \%$ & $.6 \%$ & $9.8 \%$ & $14.8 \%$ & & & \\
\hline $11 \%$ TO $30 \%$ & $5.3 \%$ & $3.4 \%$ & $7.5 \%$ & $8.7 \%$ & $38.3 \%$ & $63.1 \%$ & & & \\
\hline $31 \%$ TO $50 \%$ & $2.0 \%$ & $.8 \%$ & $1.4 \%$ & $3.9 \%$ & $9.2 \%$ & $17.3 \%$ & & & \\
\hline$>51 \%$ & $.3 \%$ & $.0 \%$ & $1.7 \%$ & $.8 \%$ & $2.0 \%$ & $4.7 \%$ & & & \\
\hline DECLINE IN GDP & $8.9 \%$ & $5.0 \%$ & $12.8 \%$ & $14.0 \%$ & $59.2 \%$ & $100.0 \%$ & 17.786 & 16 & .337 \\
\hline 9.4\% GOVERN. & $2.5 \%$ & $1.7 \%$ & $3.4 \%$ & $2.8 \%$ & $16.2 \%$ & $26.5 \%$ & & & \\
\hline $\begin{array}{l}\text { 15\% TO } 24 \% \text { EC. } \\
\text { ANALY. }\end{array}$ & $6.1 \%$ & $2.8 \%$ & $9.2 \%$ & $9.8 \%$ & $39.9 \%$ & $67.9 \%$ & & & \\
\hline $11 \%$ TO 15\% & $.3 \%$ & $.6 \%$ & $.3 \%$ & $.3 \%$ & $1.1 \%$ & $2.5 \%$ & & & \\
\hline $30 \%<$ & $.0 \%$ & $.0 \%$ & $.0 \%$ & $.6 \%$ & $.3 \%$ & $.8 \%$ & & & \\
\hline $\begin{array}{l}\text { I DO NOT } \\
\text { KNOW }\end{array}$ & $.0 \%$ & $.0 \%$ & $.0 \%$ & $.6 \%$ & $1.7 \%$ & $2.2 \%$ & & & \\
\hline
\end{tabular}

In table 4 is presented the projection of the number of employed and unemployed for the period 2020-2022. In projection of the number of employed for the period 2020-2022 by quarters we used equation of the linear regression model (empirical data for the period from 2008 to 2014 according to the date of Državni zavod za statistiku (2020b), starting point in 2008): 


$$
Y=-33.724 X+1.529 .579 \quad R 2=0,94 \quad p<0,01
$$

$X-$ year $(2008=0)$

$\mathrm{Y}$ - number of employed

Translated equation of a linear regression model starting at the end of the 1st quarter of 2020:

$Y=-33.724 X+1.64 Y=-33.724 X+1.649 .000$

In projection of the number of unemployed for the period 2020-2022 by quarters, equation of the linear regression model (empirical data for the period from 2008 to 2014 according to the date of Državni zavod za statistiku (2020b), starting point in 2008):

$$
Y=16.433 X+251.459 \quad R 2=0,86 \quad p<0,01
$$

$X-$ year $(2008=0)$

$\mathrm{Y}$ - number of unemployed

Translated equation of a linear regression model starting at the end of the 1st quarter of 2020:

$$
Y=16.433 X+129.000
$$

Table 4. Projection of the number of employed for the period 2020-2022

\begin{tabular}{|c|c|c|}
\hline QUARTER & $\begin{array}{c}\text { NUMBER OF } \\
\text { EMPLOYED }\end{array}$ & $\begin{array}{c}\text { NUMBER OF } \\
\text { UNEMPLOYED }\end{array}$ \\
\hline 1 Q2020 & $1,649,000$ & 129,000 \\
\hline 2 Q2020 & $1,640,569$ & 133,108 \\
\hline $3 Q 2020$ & $1,632,138$ & 137,217 \\
\hline $4 Q 2020$ & $1,623,707$ & 141,325 \\
\hline 1 Q2021 & $1,615,276$ & 145,433 \\
\hline $2 Q 2021$ & $1,606,845$ & 149,541 \\
\hline $3 Q 2021$ & $1,598,414$ & 153,650 \\
\hline $4 Q 2021$ & $1,589,983$ & 157,758 \\
\hline $1 Q 2022$ & $1,581,552$ & 161,866 \\
\hline 2Q2022 & $1,573,121$ & 165,974 \\
\hline 3Q2022 & $1,564,690$ & 170,083 \\
\hline 4Q2022 & $1,556,259$ & 174,191 \\
\hline & Source: Authors & \\
\hline
\end{tabular}




\section{RESULTS AND DISCUSSION}

The economic consequences caused by the COVID-19 pandemic have, since the beginning of 2020, dramatically affected the entire business management, both in the euro area and worldwide. According to ECB data released in September (2020b), the real decline in GDP in the EU was 11.8 percent in the second quarter, which is less than the expected projections of the Eurosystem experts from June 2020. This points to a strong, though not a complete, GDP recovery with a growth trend in the third quarter at a rate of 8.4 percent. Real GDP in the EU is projected to decline by 8.0 percent in 2020 and increase by 5.0 percent in 2021 and by 3.2 percent in 2022. This means that, by the end of the projection period, the level of real GDP would be 3.5 percent lower than predicted before the pandemic in the Eurosystem experts' projections from December 2019.

The crisis began in Japan and the United States, where negative (real) annual GDP change rates were recorded in 2009. Unlike the rest of the world, the Chinese economy grew (including Hong Kong) by almost 10 percent each year during the crisis, while it slowed down in the years after the crisis (Chart 1).

Chart 1. Real GDP rate of change 2009-2019

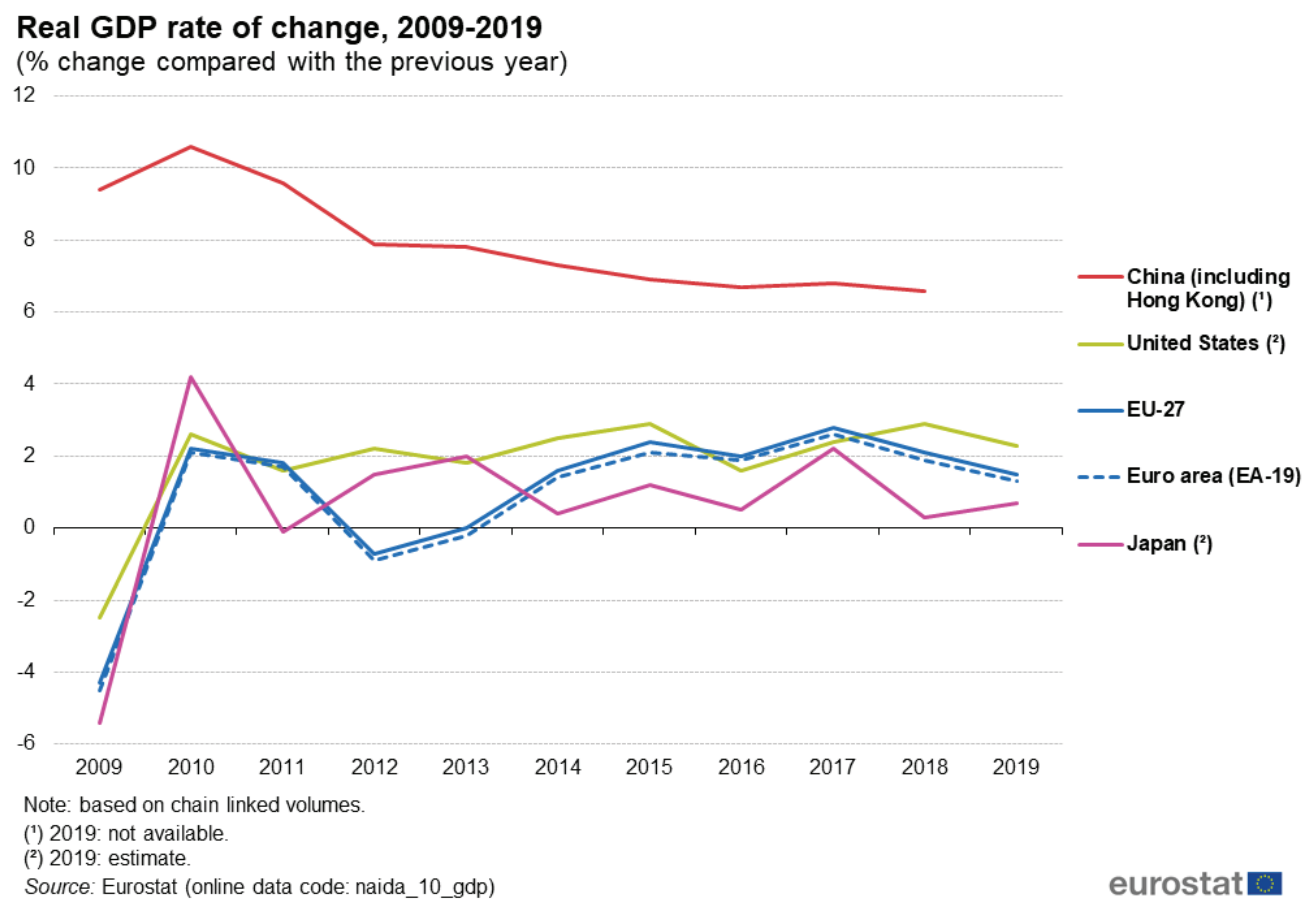

Source: Eurostar, 2020, https://ec.europa.eu/eurostat/statistics-explained/index.php?title= File:Real_GDP_rate_of_ change,2009-2019_(\%25_change compared with_the_previous_year).png (Accessed: 21.01.2021)

Looking at the global GDP, before the outbreak of the pandemic, growth rate was projected at around 3 percent, then adjusted to 1 percent, and today perhaps even lower. As the World Bank states (2020: 1): "The June 2020 global economic outlook describes the immediate and short-term 
prospects of the pandemic impact and the long-term damage it has caused to the economic growth".

According to Čavrak (2020: 5), the positive circumstance of Croatian society is that, even after the weakened economy after the crisis of 2008 to 2009, Croatia was caught in this epidemiological and economic crisis with a currency sovereignty, which Čavrak quotes as an advantage that was also noticed in the other European Union countries that still have their own currency. In contrast, the Croatian government highlighted the currency sovereignty as a shortcoming in the belief that a common European currency would provide Croatia with a simpler strategy to combat the effects of the COVID-19 virus on the economy.

\section{1 The consequences of the crises on the Croatian economy}

The crisis arrived to the Republic of Croatia a little bit later and the global economic crisis is not the only cause (only a partial one) because structural economic problems have existed from before. According Kobešćak (2014: 44) "Along with the transition, the devastation of war and the inadequate privatisation model, a misconceived economic policy that focused on price and exchange rate stability rather than the development which has not significantly changed since the country's independence, has proven itself to be the root cause of the situation". The economic growth that the Republic of Croatia had before the crisis was abruptly stopped.

As many as 69.6 percent of the entrepreneurs who have participated in the survey in early June, faced with the initial economic and life consequences of the COVID-19 crisis, have said that the consequences of this crisis will be far more severe, in Croatia, than the ones of the 2008/2009 crisis. The opinion of the respondents is confirmed by the statistics shown in Graph 2, which shows that the COVID-19 crisis had far more significant consequences than the financial crisis of 2008/09. In the second quarter of 2020, the decrease in GDP was 15.1 percent, in contrast to the financial crisis of 2008, when the GDP decrease in the second quarter was 8.8 percent. In the third quarter of 2020 , the decrease in GDP was 10 percent, in contrast to the financial crisis of 2008, when the GDP decrease in the second quarter was 8.6 percent, as shown in Graph 2. 
Graph 2. The real Growth of Quarterly GDP in Croatia

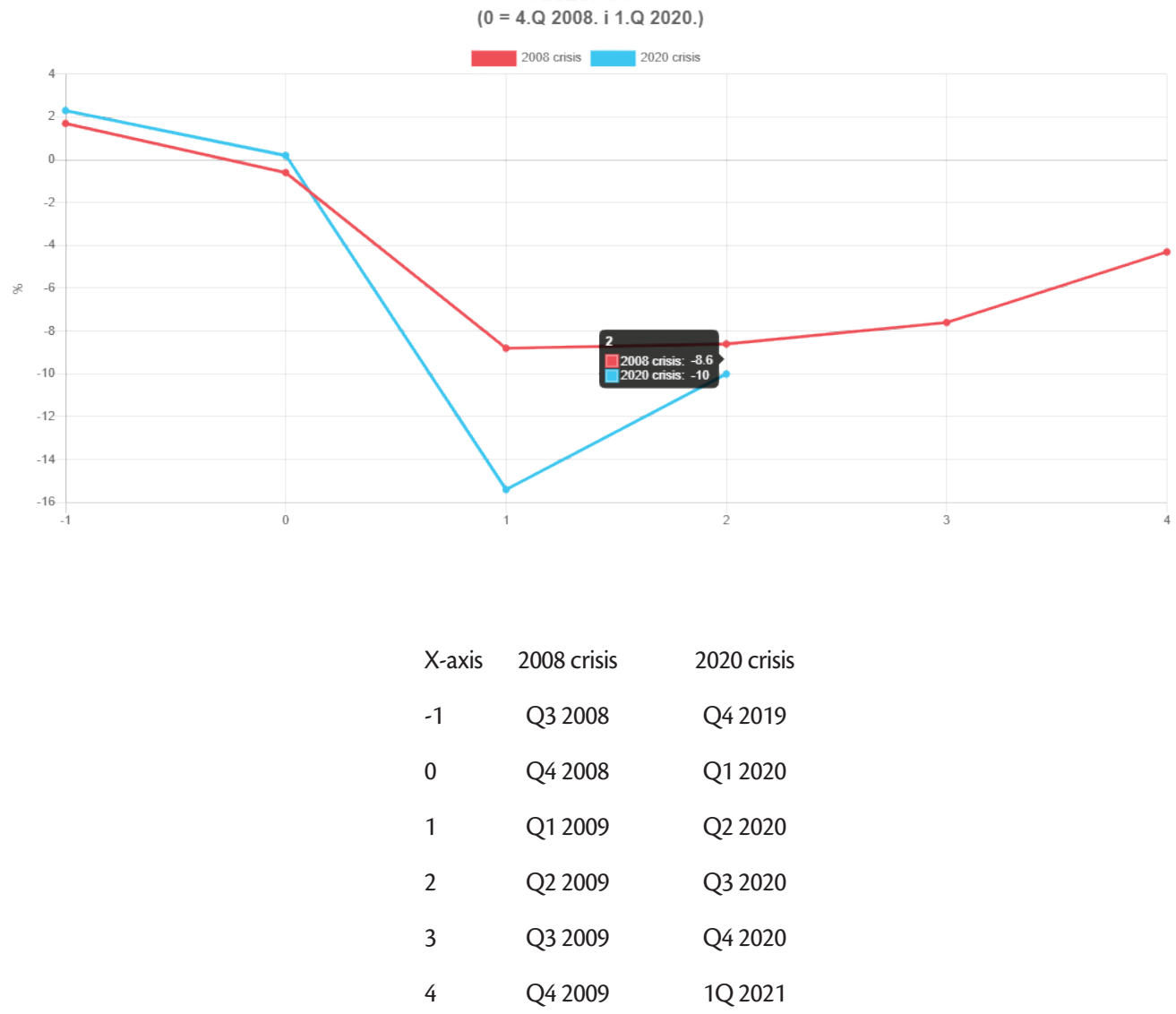

Source: Državni zavod za statistiku, 2020a, https://www.dzs.hr/Eng/Covid-19/gdp_2_q.html (Accessed: 16.01.2021)

Given the decline in the second quarter by 15 percent, Šaravanja (Privredni.hr, 2020) expects the economy to decline at double-digit rates for the whole year. He points out that this would be a bigger drop than in 2009, when the economy sank by a record 7.4 percent at the beginning of the financial crisis.

\subsection{Years of recovery from the consequences of the COVID-19 crisis in Croatia}

The global financial crisis of 2007/2008 resulted in a major recession, especially in the EU-28, and the recovery followed only in 2010 and not evenly for all countries. The Republic of Croatia recorded a six-year decline in GDP for the period of 2009 to 2014. It was only in 2015 that there was a slight growth, but once again insufficient for the overall economic recovery.

The entrepreneurs, 48.6 percent of those surveyed, informed by the experience gained during the previous financial crisis, believe the recovery from the COVID-19 crisis will take at least 3 years, 
and as many as 21.2 percent think it will take 5 years. There is no statistically significant difference between the opinion of the respondents in different phases of the COVID-19 relief measures (if they were in first, second or third phase of lockdown or they did not stop with their activities) and the years of recovery.

\subsection{Decline in employment as a consequence of the COVID-19 crisis in Croatia}

The RBA analysts (Privredni.hr, 2020) state that the largest contribution to the decline in the whole of 2020 will come from personal expenditures, due to the rising unemployment, the fall in employment and the decline of disposable income, while there will be a significant reduction or a delay in investments due to extremely high uncertainty. According to the Croatian Bureau of Statistics (Državni zavod za statistiku, 2020b), in the second quarter of 2020 the number of unemployed persons amounted to 115 thousand, which is an increase of 5.9 percent compared to the same quarter of the previous year.

Litvan (2020) states that, from mid-March to the beginning of the second week of April, the number of the unemployed rose by almost 13,000, to which tens of thousands of jobs that usually open in March due to seasonality should be added, leading to 23,000 jobs which have already been lost.

In order to prevent a larger decline in employment, the Government implement support measures to preserve the jobs, support for part-time work, self-employment, as well as assistance to microentrepreneurs.

According to the projection of the linear regression model number of unemployment will increased in the year of recovery from, like is shown in Graph 3. This projection confirms by opinion of examiners in the questionary. Although the majority of surveyed entrepreneurs (63.1 percent) predict a drop in employment 11 to 30 percent larger compared to the previous year due to the pandemic, and as many as 17.3 percent of entrepreneurs predict a drop in employment of 31 to 50 percent, it is difficult to predict what the end of the year will bring. There is no statistically significant difference between the opinion of the respondents in different phases of the COVID-19 relief measures (if they were in first, second or third phase of lockdown or they did not stop with their activities) and the declining in employment. 
Graph 3. Projection of the number of unemployed for the period 2020-2022

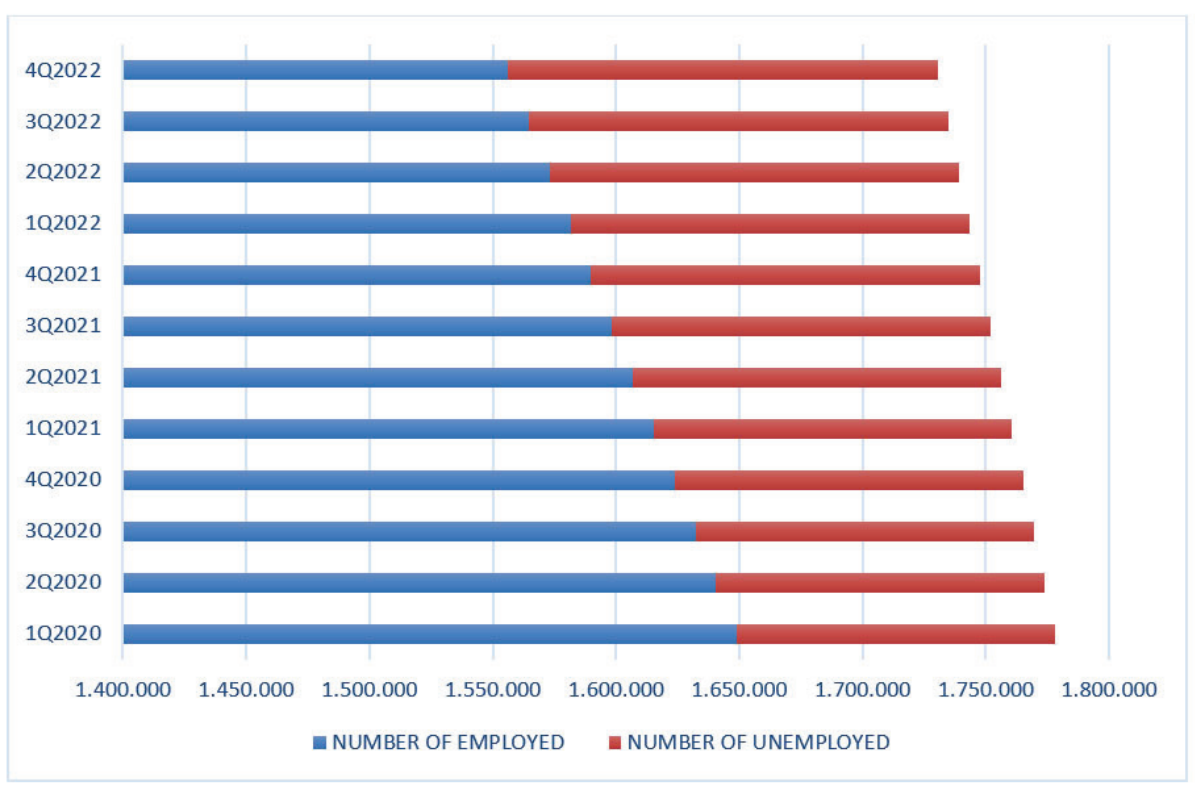

Source: Authors

\section{4 The decline of GDP in Croatia}

The government predicted of decline in GDP of 9.4 percent at the beginning of COVID-19 crisis (Jurlin, 2020). Economic analyst Šonje (Poslovni.hr/Hina, 2020) stated that according to his optimistic estimate, Croatia's GDP could fall by about 11 percent in 2020, and by 15 percent according to the more pessimistic one. In the Hina survey (Glas Slavonije, 2020), economic analysts, on average, expected a decline of 20.5 percent in the second quarter compared to the same period last year, and their estimates ranged from 15 percent to 25 percent.

Of the entrepreneurs who participated in the survey conducted in the first half of June 2020, 67.9 percent agreed with the forecasts of the economic analysts that the annual decline in GDP will be from 15 percent to 24 percent, and, it is especially significant, that 39.9 percent of the entrepreneurs who did not suspend business also chose that option. 26.5 percent of the surveyed entrepreneurs predicted a decline in GDP in the amount of the initial Government projection of 9.4 percent. There is no statistically significant difference between the opinion of the respondents in different phases of the COVID-19 relief measures (if they were in first, second or third phase of lockdown or they did not stop with their activities) and the declining of GDP.

According to the Central Bureau of Statistics data for the second quarter of 2020, GDP fell by 15.1 percent and in third quarter of 2020, GDP fell by 10 percent.

Erste Bank analysts (Wiesner, 2020) stuck to the forecast of GDP decline of 9 percent for 2020 due to the tourist season, which was better than expected. 
In September 2020, the Government (Vlada RH, 2020) adopted guidelines for drafting the state budget which project a GDP decline for 2020 of 8 percent, which is less than the initial 9.4 percent. The guidelines forecast a 5 percent growth in 2021, as well as a 3.4 percent GDP growth in 2022 and 3.1 percent growth in 2023 .

\section{CONCLUSION}

The pandemic caused by COVID-19 has led to life and economic consequences worldwide. This research, conducted on 358 entrepreneurs, aimed to establish the first picture of the economic consequences of the COVID-19 crisis, after three months of health and economic life in its clutches.

For the purposes of this research, four hypotheses were created. The first hypothesis that the according to the opinion of Croatian entrepreneurs COVID-19 crisis has and will have more significant consequences than the financial crisis of 2007/2008 (in Croatia 2008/2009) was confirmed, because 69.6 percent of the surveyed entrepreneurs voted for it.

The second hypothesis that the opinions of the entrepreneurs on the consequences of the crisis caused by the COVID-19 pandemic differ from the assumptions of the Government has been confirmed because the respondents predict a larger decline in the GDP compared to the Government.

Unlike the first two hypotheses, the third hypothesis has not been confirmed because 67.9 percent of the entrepreneurs agree with the assumptions of the economic analysts about the fall in GDP as a consequence of the crisis caused by the COVID-19 pandemic. A 15.1 percent drop in GDP in second quarter confirmed the predictions of analysts, and with that the ones of the respondents at the time of the survey.

The fourth hypothesis that there is no statistically significant difference between the opinions of entrepreneurs at various stages of post-lockdown mitigation on the economic consequences of the crisis caused by the COVID-19 pandemic in terms of GDP decline, declining of employment and the required recovery years has been confirmed. All entrepreneurs in the survey, it does not matter in which phase of easing of measures after the lockdown were, in first, second, third or they did not have any interruption of business, agreed about the declining of GDP, declining of employment and year of recovery. Opinion of entrepreneurs about the declining of employment are confirmed by linear regression model also.

The slowdown in recovery in Q4 and the unfavourable epidemiological situation will alleviate and slow something down recovery of the Croatian economy. In 2020, real GDP could decrease by 8.9\%, while in 2021 expects GDP growth of approximately 4.9\% (Croatian National Bank, 2020).

One of the main limitations of this research is that a large number of respondents in this research came from the activities of accounting, auditing and tax consulting. We can consider such a limitation in both a positive and a negative sense. The downside is that the large number of entrepreneurs, aside from being in the same industry (46.1 percent), did not have a classic lockdown but operated without interruption (36.6 percent). On the other hand, even though the 
previously mentioned activities did not have a lockdown, they all organized their activity online in compliance with the health measures in place. In the first days of lockdown, there was a lot of pressure on the accounting, auditing and tax consulting business because the deadlines for submitting the annual financial reports were rapidly approaching; many entrepreneurs had to close their businesses, so there were also problems with submitting the relevant documentation. The pressure to complete and then submit the annual financial reports to the Tax Administration and for public disclosure lasted until the adoption of the amendments to the legislation where the deadlines for submission of the annual financial statements for 2019 were extended until the end of June. However, in addition to this, bookkeeping services and tax advisors deal with filling in all the documentation of Government support, so that it is an activity that is well acquainted with the depth of the COVID-19 crisis and its consequences, not only in their business but also in the activities of their clients.

This research on the entrepreneurs' predictions of the economic consequences of the COVID-19 crisis in the first weeks of June can be used in further research and comparisons with the results achieved either later in 2020 or in subsequent years until the end of the ongoing pandemic, because any empirical research provides a certain contribution to the subsequent understanding of the aforementioned topic.

It can be concluded that the estimates of future economic trends are changing daily. There are similarities to the different possibilities of economic recession, depending on the length and the severity of the pandemic, and especially its impact on the world's leading economies.

According to the latest data, at the time of writing, many countries due to unfavourable development of the epidemiological situation tighten measures, introduced partial lockdowns in terms of the social life and the economy. All these health and economic measures indicate a significant slowdown in recovery in the last quarter 2020 and continue in the first months 2021. The start of vaccination worldwide at the end of 2020 provides opportunities to begin recovery in 2021. Many entrepreneurs, not only in Croatia, but also in the world cannot survive without a greater support from their governments. All governments, as well as the EU, need to act faster in providing financial support to the economy in order to endure and survive this COVID-19 pandemic.

\section{REFERENCES}

Baker, R.E. et al.(2020) Susceptible supply limits the role of climate in the COVID-19 pandemic; Availableat: http://medrxiv. org/content/10.1101/2020.04.03.20052787v1 (Accessed:04.10.2020) https://doi.org/10.1101/2020.04.03.20052787

Brodeur, A. et al. (2020) A Literature Review of the Economics of COVID-19, IZA Institute of Labor Economics, Discussion Paper Series; Available at: http://ftp.iza.org/dp13411.pdf

Bonadio, B. et al. (2020) Global Supply Chains inthe Pandemic (Working Paper No. 27224; Working Paper Series). National Bureau of Economic Research: https://doi.org/10.3386/w27224

Canuto, O., (2020) The Impact of Coronavirus on the Global Economy, Policy Briefs PB 20-58, Policy Center for the New South Available at: https://www.policycenter.ma/sites/default/files/PB_20-58_Canuto.pdf (Accessed: 06.10.2020) 


\section{Roška, A. Buneta, M. Papić: The effect of the COVID-19 pandemic on the Croatian economy Zbornik Veleučilišta u Rijeci, Vol. 9 (2021), No. 1, pp. 59-78}

Céspedes, L. F., Chang, R., \& Velasco, A. (2020) The Macroeconomics of a Pandemic: A Minimalist Model (Working Paper No. 27228; Working Paper Series). National Bureau of Economic Research. https://doi.org/10.3386/w27228

Coibion, O., Gorodnichenko, Y., \& Weber, M. (2020) The Cost of the Covid-19 Crisis: Lockdowns, Macroeconomic Expectations, and Consumer Spending (Working Paper No. 27141; Working Paper Series). National Bureau of Economic Research; https://doi.org/10.3386/w27141

Croatian National Bank, (2020). Brifing_za_novinare, Available at: https://www.hnb.hr/documents /20182/2952583/ hp17122020brifing_za_novinare.pdf/38f7b217-6ddd-e64a-e48c-0dc1ae8c05ee?t= 1608204039779 (Accessed: 17.01.2021)

Čavrak, V., (2020) Makroekonomija krize COCID-19i kako pristupiti njenom rješavanju, EFZG serija članaka u nastajanju,

Ćutić, D. (2020) Utjecaj pandemije bolesti COVID-19 na stabilnost PESCO programa i financiranja sigurnosnoobrambenog sektora, Strategos, 4(1), str. 51-80. Available at: https://hrcak.srce.hr/242088 (Accessed: 6.10.2020)

Državni zavod za statistiku (2020a) BDP, Available at: http://www.dzs.hr/bdp Accessed: 16.01.2021)

Državni zavod za statistiku (2020b) Available at: https://www.dzs.hr/Hrv/Covid-19/odabrani_pokazatelji.html (Accessed: 07.10.2020)

ECB (2020a). How the EU took account of lessons learned from the 2008-2012 financial and sovereign debt crises, Available at: https://www.eca.europa.eu/lists/ecadocuments/rw20_05/rw_financial_crisis_prevention_hr.pdf (Accessed: 07.10.2020)

ECB (2020b). ECB staff macroeconomic projections for the euro area, Available at: https://www.ecb.europa.eu/pub/ pdf/other/ecb.projections202009_ecbstaff 0940bca288.en.pdf

(Accessed: 02.10.2020) https://doi.org/10.1055/s-0040-1710418

Elenev, V., Landvoigt, T., \& Van Nieuwerburgh, S. (2020). Can the Covid Bailouts Save the Economy? (Working Paper No. 27207; Working Paper Series). National Bureau of Economic Research; https://doi.org/10.3386/w27207

Eurstat (2020) Available at:https://ec.europa.eu/eurostat/statistics-explained/index.php?title= File: Real_GDP_rate _of_change,_2009-2019_(\%25_change_compared_with_the_previous_year).png, (Accessed: 21.01.2021.)

Glas Slavonije (2020) Predviđanja ekonomskih analitičara: Slijedi dublja, ali puno kraća recesija nego za krize 2009, Available at: https://glas-slavonije.hr/433268/1/Slijedi-dublja-ali-puno-kraca-recesija-nego-za-krize-2009 (Accessed: 07.10.2020)

Jeffery, C. (2020). El-Erian on Covid-19 policy risks, „Zombie“ markets and central bank capture, Central banking Institute; Available at: https://www.centralbanking.com/central-banks/financial-stability/7524736/el-erian-on-covid-19policy-risks-zombie-markets-and-central-bank-capture (Accessed: 02.10.2020)

Jurlin, K. (2020) Pandemija korona virusa nokautirala globalnu ekonomiju Available at: https://www.seebiz.eu/kolumne/ pandemija-koronavirusa-nokautirala-globalnu-ekonomiju/236168/ (Accessed: 05.10.2020)

Kobešćak, M. (2014) Utjecaj sistemske korupcije na poslovnu klimu u Hrvatskoj, Diplomski rad, Sveučilište u Zagrebu Filozofski fakultet, Odsjek za sociologiju

Letica, B. (2010). Prva svjetska financijska kriza u dvadeset i prvom stoljeću: Uzroci i posljedice. DÉLKELET-EURÓPA SOUTH-EAST EUROPE. INTERNATIONAL RELATIONS QUARTERLY, Vol. 1. No. 3 (AUTUMN 2010 ÖSZ). Available at: https://www.southeast-europe.org/pdf/03/DKE_03_H_T_BAL.pdf (Accessed: 02.10.2020)

Litvan, G. (2020): 100 Vladinih mjera za spas gospodarstva, Lider Vodič za preživljavanje: 100 mjera za spas gospodarstva, Special Issue, pp. 4-7

Maliszewska, M., Mattoo, A., van der Mensbrugghe, D. (2020). The Potential Impact of COVID-19 on GDP and Trade : A Preliminary Assessment. Policy Research Working Paper;No. 9211. World Bank, Washington, DC. ๑ World Bank. Available at: https://openknowledge.worldbank.org/handle/10986/33605 (Accessed: 05.10.2020) https://doi. org/10.1596/1813-9450-9211 
Poslovni.hr/Hina (2020) Ekonomski analitičar: Optimističan pad BDP-a 11 posto, a prema pesimističnoj procjeni... Available at: https://www.poslovni.hr/hrvatska/sonje-optimistican-pad-bdp-a-11-posto-a-premapesimisticnoj-procjeni-4235712 (Accessed: 05.10.2020)

Privredni.hr (2020) Očekuje se rekordan pad BDP-a i u cijeloj 2020: « Najgore je prošlo, dno je dosegnuto », Available at: https://privredni.hr/analiticari-ocekuju-rekordan-pad-gospodarstva-i-u-cijeloj-2020-godini (Accessed: 05.10.2020)

Vlada RH (2020) U 2021. godini rast gospodarstva pet posto, Available at: https://vlada.gov.hr/vijesti/u-2021-godinirast-gospodarstva-pet-posto/30437 (Accessed: 07.10.2020)

Wiesner, V. (2020), Analitičari Erste banke: Pad BDP-a u 2020. bit će 9 posto, turistička sezona bila je bolja od očekivanja, Availabe at: https://www.vecernji.hr/vijesti/analiticari-erste-banke-pad-bdp-a-u-2020-bit-ce-9-posto-turistickasezona-bila-je-bolja-od-ocekivanja-1431999 (Accessed: 07.10.2020)

World Bank, (2020), The Global Economic Outlook During the COVID-19 Pandemic: A Changed World; Available at: https://www.worldbank.org/en/news/feature/2020/06/08/theglobal-economic-outlook-during-the-covid-19pandemic-a-changed-world (Accessed: 07.10.2020) 


\title{
UTJECAJ COVID-19 PANDEMIJE NA HRVATSKO GOSPODARSTVO
}

\author{
Vlasta Roška \\ Dr. sc., docentica, Libertas međunarodno sveučilište, Fakultet za međunarodno poslovanje i ekonomiju, \\ Trg J. F. Kennedy 6b, 10000 Zagreb, Hrvatska; e-mail: vroska@libertas.hr
}

\section{Anđelka Buneta}

Dr. sc., viša predavačica, Libertas međunarodno sveučilište, Fakultet za međunarodno poslovanje i ekonomiju, Trg J. F. Kennedy 6b, 10000 Zagreb, Hrvatska; e-mail: andelka.buneta1@gmail.com

\section{Milan Papić}

Mr. sc., viši predavač, Libertas međunarodno sveučilište, Fakultet za međunarodno poslovanje i ekonomiju, Trg J. F. Kennedy 6b, 10000 Zagreb, Hrvatska; e-mail: mpapic@libertas.hr

\section{SAŽETAK}

Članak pod naslovom „Utjecaj COVID-19 pandemije na hrvatsko gospodarstvo“ bavi se vrlo aktualnim događajima izazvanim pandemijom, a koje se odrazilo na nacionalno i globalno gospodarstvo. $\mathrm{Na}$ temelju trenutno raspoloživih podataka i provedene ankete na 358 ispitanika (iz realnog sektora i javne uprave) u radu se analiziraju posljedice COVID-19 na hrvatsko gospodarstvo promatrano kroz pad zaposlenosti, potrebne godine oporavka te pad BDP. Također su analizirane sličnosti i razlike sa velikom svjetskom ekonomskom krizom 2008/2009 godine te je ispitano mišljenje poduzetnika o tome koja kriza ima značajnije posljedice za gospodarstvo. Modelom linearne regresije je predviđen pad zaposlenosti u godinama oporavka. Poduzetnici su složni u procjeni da je kriza uzrokovana COVID-19 pandemijom daleko razornija i pogubnija za gospodarstvo, prvenstveno stoga jer joj se ne nazire kraj usprkos pronalasku cjepiva. Jednoglasna je poruka poduzetnika da bez daljnjih mjera za očuvanje gospodarstva od strane Vlade neće se moći zadržati daljnji pad zaposlenosti, kao i BDP-a, što će dovesti do produljenja potrebnog vremena oporavka hrvatskog gospodarstva. Ovo istraživanje je osnova za buduća istraživanja utjecaja COVID-19 pandemije na hrvatsko gospodarstvo.

Ključne riječi: COVID-19 kriza, zaposlenost, financijske krize, BDP 